\title{
SHELTER RESEARCH IN AGRICULTURE AND HORTICULTURE
}

$\mathrm{M}$ ANY agricultural improvors of the eighteenth and early nineteenth centuries attached considerable importance to providing sheltering woodlands for exposed farmland, while horticultural enterprises in mild but windy coastal areas of the United Kingdom have long appreciated the need for shelter. The actual benefits of shelter havo, however, romained difficult to evaluate.

On the reconstruction of the Agricultural Improvement Council in 1952, the problems of shelter were raised and in 1955 its Land Management Committee decided that more information was needed about the nature of shelter itself and its effects on stock and crops. The Sholter Research Planning Group was formed to assess these probloms and indicate the order of priority with which these might bo investigatcd. It was clear at the outset that many aspects roquiring investigation encroached on different spheres of scientific activity and cut across existing fields of scholarship and study: biology, meteorology, acrodynamics and even engineering.

During 1952-53 the Forestry Commission financed research at the Univorsity of Edinburgh into the influences of shelter-belts on microclimate, with the ultimate object of designing appropriate types of windbreak for different purposes in agriculture, horticulture and forestry. In the spring of 1953 pilot investigations of horticultural shelter were begun at selocted experimental horticultural stations in conjunction with the Agricultural Branch of the Meteorological Office. Afterwards, on the Agricultural Improvement Council's recommendation, the Ministry of Agriculture sponsored projects concerned with livestock shelter at the University College of Wales, Aborystwyth, University College of North Wales, Bangor, and King's College, Newcastle.

A good deal of research, directly and indirectly relevant to the question of shelter, continued to be pursued in separate but allied fields, and in 1959 the Shelter Research Planning Group appointed Dr. J. M. Caborn, University of Edinburgh, to keep in touch with this work and act as a focal point to which information might be sent or inquiries addressed.

It was also realized that, in a comparatively new field of study, much time and effort were inevitably duplicated, particularly during the 'teething troubles' of devising experimental techniques and equipment. Any concerted or co-ordinated attack on the basic problems could only come from closer communications between research workers in the various fields involved. Accordingly, a symposium on shelter resoarch was organized recently at Aberystwyth by the Shelter Research Planning Group.

After the opening by Mr. R. G. A. Lofthouse, chairman of the Group, the first session was devoted to "The Shelter Needs of Horticulture, Methods of Providing Shelter and Plant Response". Mr. F. W. Shepherd, deputy director, East Midland Region, National Agricultural Advisory Service, and former director, Rosewarne Experimental Horticulturo Station, examined the case for shelter based on long experience of tho horticultural areas of south-west Fingland and presented results of trials of tree and shrub species for sholter hedges. Mr. W. H. Hogg, senior meteorological officer, attached to the N.A.A.S., Bristol, outlined the experiments with horticultural shelters which have continued at Rosewarne and other centres, reviewing Continental experionce in this field and concluding with a deseription of wind survey tochniques derived to assess the need for further shelter, other than that contributed by topography.

Sholter for livestock occupied a major part of the programme, and the discussion was opened by Dr. K. L. Blaxter of the Hannah Dairy Research Institute, Ayr, with a paper on "The Reactions of Cattle and Sheep to the Stress of Cold Environments". This dealt with procision studies of physiological and nutritional responses of animals exposed to controlled conditions in calorimoters and preliminary extension of these techniques to outdoor conditions. $\mathrm{He}$ concluded that, while quantitative expression can now be given to the effocts of still-air environments on tho metabolism of sheep and cattle, similar information is urgently needed for the effects of wind and rain. It was also emphasized that the separation of the direct stresses of climatic environment from the indirect ones, for example, lack of food, while instructive in laboratory studies, does not occur under field conditions. Prof. J. E. Nichols, University College of Wales, discussed the more pragmatic approach to the problem, for example, continued observation of individual and flock response to adverse weather conditions under normal systems of managernent.

A third session heard a paper by Dr. R. W. Gloyne of the Meteorological Office on "Meteorological Techniques in Shelter Research", especially in relation to livestock in hill areas. This included details of instrumentation available for measuring weather phenomena, illustrated by an account of methods applied for investigating long-term influences of introducing a series of shelter plantations on an exposed hill at Bangor. Mr. R. Lines of the Forestry Commission followed with an account of certain shelter experiments on tree growth, and described the technique of assessing comparative exposure by means of observing the rate of tattering of unhemmed linen flags. Finally, Dr. J. M. Caborn spoke on "Assessing the Efficiency of Shelter", dealing with methods of measuring the shelter performance of shelter-belts and windbreaks and discussing the value of shelter on the farm. Although there seemed little prospect of being able to forecast shelter offect on arablo crop production from the basis of particular levels of wind. a plea was made for preliminary investigations into the effect of existing shelterbelts on the yicld of field crops under Britain's climatic conditions.

Closing the proceedings, the chairman referred to the considerable exchange of information, ideas and experiences made possible by this meeting, in both formal and informal discussion. It was generally felt that the whole subject had gained momentum and that various sections of activity, though independent, promised to dovetail in the future and prosent a more composite picture of this very diffuse question of shelter.
J. M. CABORN 